\title{
Production and characterization of miro- and nano-features in biomedical alumina and zirconia ceramics using a tape casting route
}

\author{
Maciej Domanski $\cdot$ Louis Winnubst • \\ Regina Luttge $\cdot$ Edwin Lamers $\cdot X$. Frank Walboomers • \\ John Jansen • Han Gardeniers
}

Received: 8 December 2011/Accepted: 27 March 2012/Published online: 20 April 2012

(C) The Author(s) 2012. This article is published with open access at Springerlink.com

\begin{abstract}
A process of micromolding, delivering microand nanopatterned ceramic surfaces for biomaterial applications is described in this work. To create the desired structures, tape casting of ceramic slurries on microfabricated silicon mold was used. Several tape casting slurry compositions were tested to evaluate the feasibility of transferring micro- and nano-features from silicon molds. Used ceramics were alumina $\left(\alpha-\mathrm{Al}_{2} \mathrm{O}_{3}\right)$ and yttria stabilized zirconia. Three types of polymeric binders for the green tape (PVB, PES, and PVP) were investigated using three different solvents (ethanol, $n$-methyl-pyrrolidone, water). Well-defined features in shapes of wells with diameters down to $2.4 \mu \mathrm{m}$ and a depth of $10 \mu \mathrm{m}$ and pillars with diameters down to $1.7 \mu \mathrm{m}$ and a height of $3 \mu \mathrm{m}$ were obtained. Morphology, grain size and porosity of the sintered bodies were characterized. Finally fibroblast cells were cultured on the surfaces in order to observe their morphology under influence of the microstructured surfaces.
\end{abstract}

M. Domanski $(\bowtie) \cdot$ R. Luttge $\cdot$ H. Gardeniers

Mesoscale Chemical Systems, MESA+ Institute for

Nanotechnology, University of Twente, P.O. Box 217,

7500 AE Enschede, The Netherlands

e-mail: maciejmd@gmail.com

\section{Winnubst}

Inorganic Membranes, MESA+ Institute for Nanotechnology,

University of Twente, P.O. Box 217, 7500 AE Enschede,

The Netherlands

E. Lamers - X. F. Walboomers - J. Jansen

Department of Biomaterials, Radboud University Nijmegen

Medical Centre, P.O. Box 9101, 6500 HB Nijmegen,

The Netherlands

\section{Introduction}

Historically, ceramic biomaterials, such as alumina and zirconia, were anticipated to function as an inert material in the body. Nowadays the emphasis is more on applying these materials to create a bioactive scaffold that stimulates the construction of a well-functioning bone-implant interface [1-4]. It is often stated that a specific combination of micro- and nanotopography is required to stimulate osteoinduction or to cause mechanisms like mechanical anchoring of implant in the body, stimulate cells to produce a higher density of focal adhesions [5-7] or even to present an antibacterial effect [8]. Naturally occurring submicrometer range stochastic surface features on ceramics emerge from the intrinsic grainy nature of this group of materials. In addition to this "natural" nanostructure, in this study we will define micro-pillars, micro-wells and sub-micron sized ridges and grooves prepared by tape casting using microfabricated silicon as casting molds. Ceramic materials used here were yttria stabilized zirconia (YSZ) and alumina $\left(\alpha-\mathrm{Al}_{2} \mathrm{O}_{3}\right)$, which have a long history as implantation materials, both as a bulk material or in form of coatings $[9,10]$. Such inert oxide ceramics are generally used in applications where good mechanical and tribological characteristics, that are unique for this group of materials, are required [1, 2, 9-11].

In fabrication process, tuning the ceramic slurry parameters allows us to obtain the desired bioceramics morphology, porosity, mechanical strength and surface micro- and nanotopography [12-16]. We evaluated three types of typical tape casting slurries based on different binders and solvents, and five types of microfabricated silicon mold masters with different micro-feature dimensions $(10,5,2$, and $0.5 \mu \mathrm{m})$. The casting slurry recipes were adapted from respective tape casting methodologies 
[12], ceramic hollow fiber fabrication by a phase inversion method [13] and colloidal filtration methods [14]. The micro-features in the silicon molds consisted of pillar- or well-like structures arranged in a trigonal lattice. To evaluate the dimensional limits of pattern transfer, casting was also performed on submicrometer silicon features with ridge and groove shapes. After casting, the green tapes were either air-dried or solvent was exchanged with nonsolvent. The resulting green tapes were sintered and characterized with scanning electron microscopy (SEM) and densitometry. Finally, the produced size-resolved surface topographies were used in biological experiments, from which it was concluded that fibroblast cells respond to surface topography by altering their morphology. Although our research focused on YSZ and $\alpha-\mathrm{Al}_{2} \mathrm{O}_{3}$, which are well recognized ceramic materials in biomaterial applications, we would like to stress that any type of ceramic material can be structured utilizing the versatile method presented in this work.

\section{Materials and methods}

\subsection{Mold masters for tape casting}

Masters were microfabricated using UV lithography for feature dimensions of $10,5,2 \mu \mathrm{m}$ or laser interference lithography (LIL) for $0.5 \mu \mathrm{m}$ features. Subsequently the pattern was transferred into silicon using reactive ion etching. In brief the fabrication of mold masters using UV lithography was conducted as follows: a 100-mm, standard $\{100\}, p$-type, one side polished silicon wafer (Okmetic, Finland) was spin-coated with positive i-line photo resist (OiR 907/17, Fujifilm) and subsequently exposed through a prefabricated chromium-on-glass mask using UV optical lithography. The exposure dose was $34 \mathrm{~mJ} \mathrm{~cm}^{-2}$. The latent structure was developed in OPD 4262 developer for $60 \mathrm{~s}$ (Fujifilm). Following lithography and development, deep reactive ion etching (DRIE) with a Bosch-type process was conducted with $\mathrm{SF}_{6}$ plasma composition in etching mode and $\mathrm{C}_{4} \mathrm{~F}_{8}$ plasma in passivation mode in an ICP source type RIE equipment at $-10{ }^{\circ} \mathrm{C}$ using liquid nitrogen substrate holder cooling (Adixen AMS100SE, Alcatel).

For the LIL delivered structure a tri-layer resist system was spin-coated on a silicon wafer using OPTIcoat ST22 ${ }^{+}$ equipment (Sister Semiconductor). The stack consisted of: a DUV30-J6 bottom antireflective coating (BARC, Brewer Science), positive photoresist (PEK-500 chemically amplified resist, Sumitomo Chemical) and an Aquatar-6A top antireflective coating (TARC, Brewer Science). It was found that configuration of layers of $13 \mathrm{~nm}$ BARC, $140 \mathrm{~nm}$ photoresist, and approximately $5 \mathrm{~nm}$ TARC gave optimum stability and a high structural resolution under ambient conditions. In the lithographic step, a fourth harmonic continuous-wave yttrium aluminum garnet laser MBD 266 system (Coherent Inc., USA) with a wavelength of $266 \mathrm{~nm}$ was used as the coherent light source. A Lloyd's mirror interference setup was utilized as an interference pattern generator creating latent ridge and groove pattern. Exposures of the resist were done with a dose of $4.5 \mathrm{~mJ} \mathrm{~cm}^{-2}$. A post-exposure bake was performed for $90 \mathrm{~s}$ at $105^{\circ} \mathrm{C}$. After lithography, latent resist patterns were manually developed for $45 \mathrm{~s}$ in $75 \% \mathrm{v} / \mathrm{v}$ OPD 4262 in water (Fujifilm Electronic Materials). The first etching step, removing the BARC, was conducted in an oxygen plasma applying $280 \mathrm{~W}$ power, $1 \mathrm{~Pa}$ pressure $8 \mathrm{sccm} \mathrm{O}_{2}$ gas flow, and $18 \mathrm{~s}$ etching time. After oxygen plasma step, the system was switched to a $\mathrm{SF}_{6}: \mathrm{O}_{2}$ plasma composition and the silicon etching process was continued in standard RIE mode. The etching was carried out in a PlasmaTherm 790 (Unaxis) parallel plate etcher at $10{ }^{\circ} \mathrm{C}$ using substrate stage water cooling.

After etching the silicon molds were cleaned in fuming nitric acid for $10 \mathrm{~min}$ in order to remove residues of resist. Few types of anti-adhesion coatings on silicon molds were fabricated. Molds were sputtered with a thin layer of one of the materials: gold, titanium, chromium or aluminum (below $200 \mathrm{~nm}$ ) using an argon plasma sputtering system with $200 \mathrm{~W}$ RF power (Sputterke, TCO) or a thin layer of carbon fluorides was deposited using plasma enhanced chemical vapor deposition (PECVD) using $\mathrm{C}_{4} \mathrm{~F}_{8}$ (Adixen 100 SE, Alcatel).

\subsection{Preparation of ceramic slurries}

The starting ceramic powders were either $\alpha-\mathrm{Al}_{2} \mathrm{O}_{3}$ (Sumitomo AKP 30, particle size range 0.3-0.5 $\mu \mathrm{m}$, surface area typically $5-10 \mathrm{~m}^{2} \mathrm{~g}^{-1}$ ) or YSZ (Tosoh Zirconia, TZ-8YS, particle size range $0.05-0.08 \mu \mathrm{m}$, surface area typically 5-9 $\mathrm{m}^{2} \mathrm{~g}^{-1}$ ). Three types of tape casting slurries were prepared: water based (referred to as $\mathrm{PVP}-\mathrm{H}_{2} \mathrm{O}$ ), ethanol based (referred to as PVB-EtOH) and n-methylpyrrolidone based (referred to as PES-NMP). The slurry compositions are summarized in Table 1.

\subsubsection{Organic solvent based slurries}

For preparation of ethanol and NMP based tape casting slurries two types of polymeric binders were used: PVB and PES, respectively (polyvinyl butyral, Tapecasting Warehouse INC and polyethersulfone, Goodfellow Cambridge Limited). First step of slurry preparation consisted of dissolving oven-dried polymers $\left(50{ }^{\circ} \mathrm{C} / 24 \mathrm{~h}\right)$. For PVB $99.9 \%$ ethanol and for PES $99.9 \%$-methylpyrrolidone (Sigma Aldrich) were used as the solvents. The polymersolvent mixtures were stirred on a roller bench during $3 \mathrm{~h}$ 
Table 1 Composition of the tape casting slurries used for micromolding (weight $\%$ )

\begin{tabular}{|c|c|c|c|c|c|c|}
\hline \multirow{2}{*}{$\begin{array}{l}\text { Composition } \\
\text { Viscosity of slurry }\end{array}$} & \multicolumn{2}{|l|}{$\begin{array}{l}\text { PVB-ethanol based slurry } \\
\text { (PVB-EtOH) }\end{array}$} & \multicolumn{2}{|l|}{ PVP-water based slurry } & \multicolumn{2}{|l|}{$\begin{array}{l}\text { PES- } n \text {-methyl-pyrrolidone based } \\
\text { slurry (PES-NMP) }\end{array}$} \\
\hline & $\sim 2,500 \mathrm{mPa}$ & & $\sim 6,000 \mathrm{mPa}$ & & $\sim 9,500 \mathrm{mPa}$ & \\
\hline Ceramic powder & $\alpha-\mathrm{Al}_{2} \mathrm{O}_{3}$ & $42.9 \%$ & $\alpha-\mathrm{Al}_{2} \mathrm{O}_{3}$ & $46.3 \%$ & $8 \mathrm{~mol} \% \mathrm{Y}_{2} \mathrm{O}_{3}$ stabilized $\mathrm{ZrO}_{2}$ & $50.7 \%$ \\
\hline Binder & Polyvinyl butyral, $\mathrm{PVB}^{\mathrm{b}}$ & $6.4 \%$ & Polyvinylpyrrolidone (PVP) & $4.5 \%$ & Polyethersulfone PES ${ }^{\mathrm{b}}$ & $4.9 \%$ \\
\hline Solvent & Ethanol & $46.6 \%$ & $0.02 \mathrm{M}$ nitric acid in $\mathrm{H}_{2} \mathrm{O}$ & $46.2 \%$ & n-methyl-2-pyrrolidone (NMP) & $44.4 \%$ \\
\hline Dispersant & Solsperse $20000^{\mathrm{a}}$ & $0.8 \%$ & Disperbyk $194^{c}$ & $3 \%$ & & \\
\hline Plasticizer & Butyl benzyl phthalate ${ }^{\mathrm{b}}$ & $2.8 \%$ & & & & \\
\hline Dispersant & Menhaden fish oil ${ }^{\mathrm{a}}$ & $0.5 \%$ & & & & \\
\hline
\end{tabular}

${ }^{\mathrm{a}}$ The Lubrizol Corporation, USA, ${ }^{\mathrm{b}}$ Tapecasting Warehouse, Inc., USA, ${ }^{\mathrm{c}}$ BYK-Chemie GmbH, Germany

in a 1 liter poly-ethylene bottle together with $1 \mathrm{~cm}$ diameter alumina balls. Next, the tape casting additives as given in Table 1 were added. Additives used in PVB-EtOH based slurry were: Menhaden Fish Oil and Butyl Benzyl Phthalate as plasticizer (Richard E. Mistler, Inc.) and Solsperse 20000 as dispersant (The Lubrizol Corporation). For the PES-NMP based slurry no dispersants or plasticizers were used. The solutions were mixed for one more hour. Oven dried $\left(60^{\circ} \mathrm{C}, 24 \mathrm{~h}\right)$ alumina or zirconia powders were added to the polymer-solvent solutions and the slurries were mixed on a roller bench for another $24 \mathrm{~h}$. Finally, slurries were degassed in ultrasonic bath for $20 \mathrm{~min}$

\subsubsection{Water based slurry}

To prepare the water based slurry, the alumina ceramic powder was dispersed in $0.02 \mathrm{M}$ aqueous nitric acid solution. The powder to solvent ratio was 1:1 (w/w). Next, the suspension was sonicated using a horn sonicator for $7 \mathrm{~min}$ (S-250, Branson Ultrasonic). Finally polyvinylpyrrolidone polymer (PVP, Aldrich, $\left.M_{\mathrm{w}}=1,300,000\right)$ and Disperbyk194 (BYK-Chemie $\mathrm{GmbH}$ ) dispersant were added and the suspension was mixed for $4 \mathrm{~h}$ on a roller bench.

\subsection{Tape casting on silicon masters and sintering}

A thin (1-3 mm) layer of ceramic slurry was deposited on the silicon master by using a doctor's blade. Next, depending on the slurry type, green tapes were slowly air dried in ethanol-vapor rich environment (for PVB-Ethanol based slurry) or in moist air (for PVP-water slurry), obtained by closing the sample together with a Petri dish filled with either ethanol or water in a $10 \times 10 \times 5 \mathrm{~cm}^{3}$ polymer box with a $0.5 \times 0.5 \mathrm{~cm}^{2}$ hole in the top that caused slow diffusion-driven air-solvent exchange. After drying the green tapes were manually separated from the masters. The PES-NMP based green tape was prepared using a phase inversion method. The slurry was casted on the mold master and subsequently immersed in water to cause liquid-solid phase separation. This solvent/non-solvent exchange in the slurry causes solidification of PES [17]. Finally the samples were manually removed from the master, and dried for $72 \mathrm{~h}$. The dried green tapes were cut in $5 \times 5-\mathrm{mm}^{2}$ pieces and sintered in a tube furnace (Vectstar, type $6 \mathrm{Z}$ ) at $1,500{ }^{\circ} \mathrm{C}$. Sintering profiles were designed as follows: heating at $1{ }^{\circ} \mathrm{C}$ per minute to $400{ }^{\circ} \mathrm{C}$, binder burn-out at $400{ }^{\circ} \mathrm{C}$ for $1 \mathrm{~h}$, heating up to $1,500{ }^{\circ} \mathrm{C}$, sintering for $4 \mathrm{~h}$, and finally cooling down to room temperature at $3{ }^{\circ} \mathrm{C}$ per minute.

\subsection{Density and grain size measurement}

For the sintered ceramics grain size analysis was performed, utilizing the linear intercept method for analysis of SEM scans. Sintered specimens were polished using diamond polishing media (Cameo method, LamPlan). Next specimens were thermally etched in a tube furnace by heating up to $1,230{ }^{\circ} \mathrm{C}$ and keeping the specimens at that temperature for $45 \mathrm{~min}$ in order to reveal the grains. After this treatment both zirconia and alumina specimen were sputter coated with a thin gold layer and investigated by SEM. Image analysis utilizing ImageJ software was used to measure the average grain size with the line intercept method (Mendelson method, Fig. 5) [18]. Density of the sintered ceramics was measured with the Archimedes' method [19] in mercury using a laboratory scale (Mettler Toledo PB1502S). The detailed morphology of specimens was investigated with SEM. All SEM scans included in this work were made on Jeol JSM-5610LV, Jeol 6310 SEM or Philips XL 30 ESEM-FEG electron microscopes.

\subsection{Cell culture study}

Rat dermal fibroblasts (RDF) were obtained from the ventral skin of male Wistar rats as described by Freshney [20]. Cells were cultured in $\alpha$-MEM medium (Invitrogen) supplemented with $10 \%$ Fetal Calf serum (FCS) and 
gentamicin $\left(50 \mu \mathrm{g} \mathrm{ml}^{-1}\right)$. Cell culture experiments were performed at the 6 or 7 th culture passage. Before transferring the cells to the substrates, cells were detached from the culture flask using trypsin/EDTA $(0.25 \%$ w/v trypsin/ $0.02 \%$ EDTA) (Invitrogen) and concentrated by centrifugation at $1,500 \mathrm{rpm}$ for $5 \mathrm{~min}$. Subsequently, cells were resuspended in the culture medium, quantified using a Coulter ${ }^{\circledR}$ counter (Beckman Coulter Inc.) and seeded at a density of $1 \times 10^{4}$ cells $\mathrm{cm}^{-2}$. Fibroblast cell culture assays were performed on well- and pillar-like structures of $\alpha$-alumina substrates acquired from PVB-EtOH slurries in the time of 2 days of seeding. Thereafter cells were fixed in $2 \%(\mathrm{w} / \mathrm{v})$ glutaraldehyde in $0.1 \mathrm{M}$ sodium-cacodylate, dehydrated in a graded series of ethanol (from 70 up to $100 \%$ ), and dried to air in tetramethylsilane. The substrates were sputter coated with gold and observed using a Jeol 6310 SEM.

\section{Results and discussion}

\subsection{Ceramics fabrication}

SEM micrographs of etched silicon molds of UV lithography delivered well- and pillar-like structures and the LIL delivered ridge and groove structures are presented in Fig. 1. It is clearly visible that uniform patterns can be obtained with the microfabrication techniques used in this work. Slightly negative tapers in etched pillars and wells obtained by the DRIE process can be of an additional advantage in flawless mold release; however, the influence of this was not studied in this work. In order to facilitate easy demolding an anti-adhesion layer was deposited on the mold surface. The role of the anti-adhesion layer was to facilitate demolding by lowering adhesion of binder polymer to the silicon microstructure. We have tested five different surface coatings: sputtered gold, titanium, chromium, alumina or PECVD of $\mathrm{C}_{4} \mathrm{~F}_{8}$. In order to choose the method facilitating the most complete release of green tape from the mold, all surfaces coatings were evaluated with all water and organic solvent slurries. For the phase inversion system utilizing NMP-based the anti-sticking coating of carbon fluorides gave the best results and for water and ethanol based slurries gold was the most satisfying choice, guaranteeing the most complete surface features replication. The thickness of the metal coating was below $200 \mathrm{~nm}$ and did not significantly change the dimensions of the surface features.

After tape casting and demolding, the green tapes were examined with SEM. In the acquired micrographs the dispersed particles of ceramics suspended in the polymer matrix could be observed as bright dots in contrast to more electron adsorbing and thus darker polymer matrix (Fig. 2).
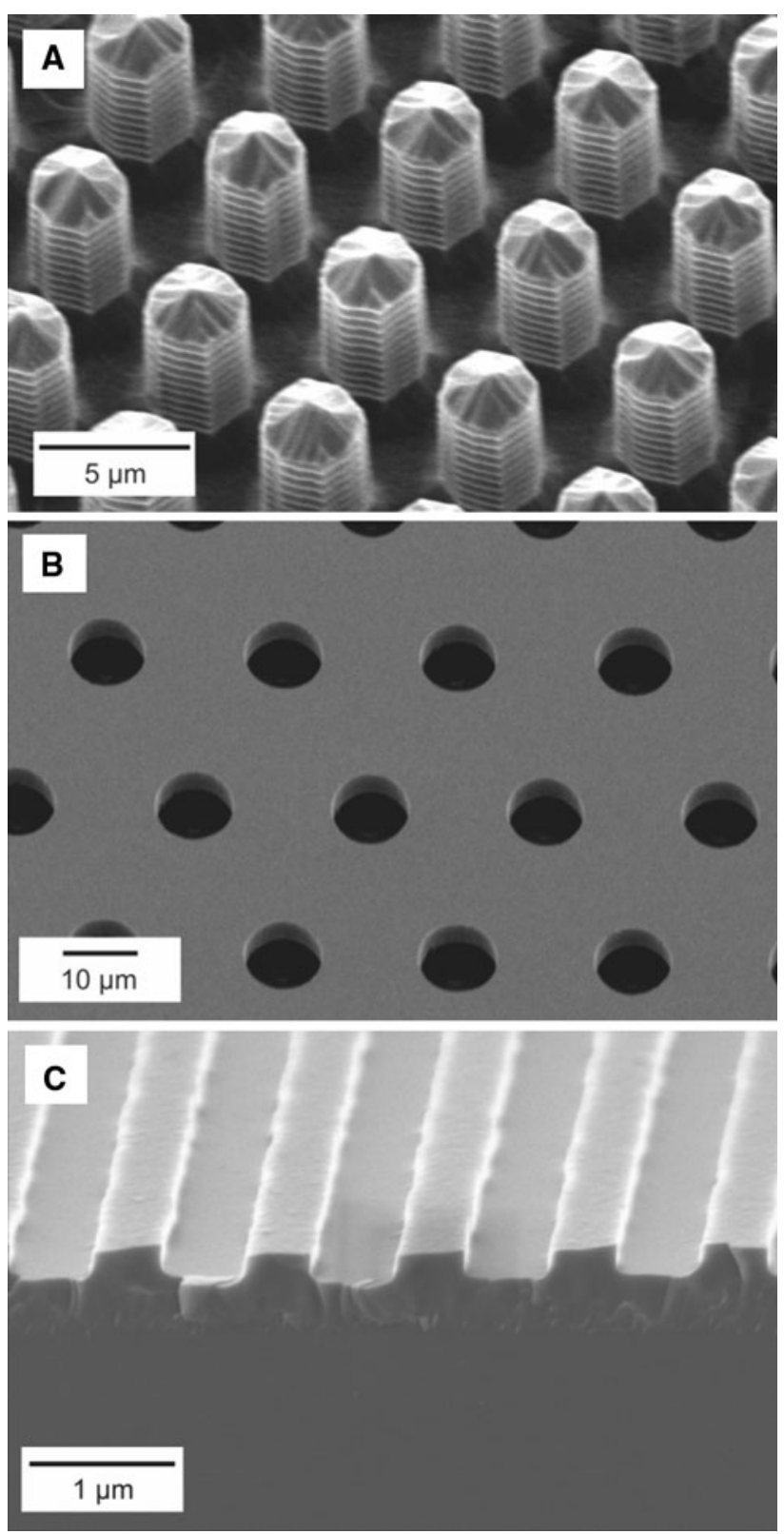

Fig. 1 Scanning electron micrographs of silicon mold masters fabricated with UV lithography (a, b), LIL (c) lithography and subsequent RIE. a $2 \mu \mathrm{m}$ pillar structure in silicon. b $10 \mu \mathrm{m}$ well structure etched in silicon. c $0.5 \mu \mathrm{m}$ ridges in silicon

No large agglomerates of ceramic particles were observed for all types of green tapes. This suggests that the dispersion stabilization by either polymer additives or $\mathrm{pH}$ adjustment was successful. The PVB-EtOH and PESNMP based slurries gave robust easy to handle green tapes, facilitating further shaping (i.e., in bone implant shape) whereas $\mathrm{PVP}-\mathrm{H}_{2} \mathrm{O}$ based slurry gave mechanically brittle green tapes. For all casting methods used the demolding process results in up to $99 \%$ of complete and defect-free green tapes, for both pillars and wells. 


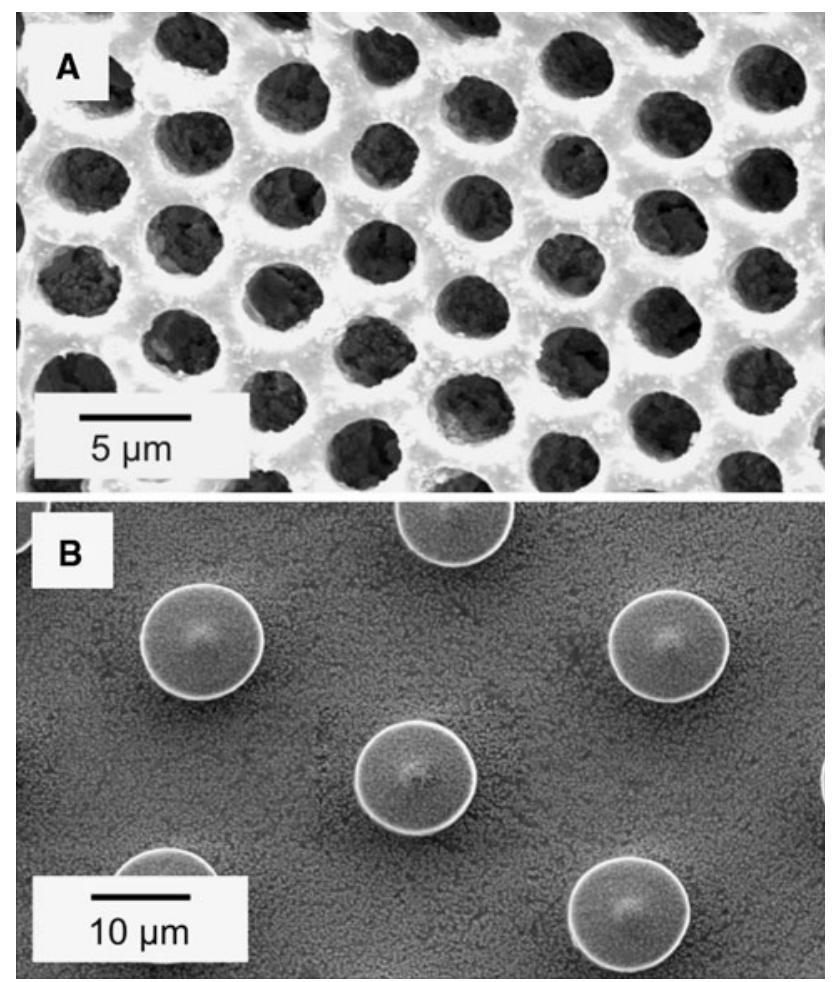

Fig. 2 Green tapes with visible polymer-ceramic composite before sintering. a $2 \mu \mathrm{m}$ well structure created in $\mathrm{ZrO}_{2}$ with PES-NMP slurry. b $10 \mu \mathrm{m}$ pillar structure created in $\mathrm{Al}_{2} \mathrm{O}_{3}$ with $\mathrm{PVP}-\mathrm{H}_{2} \mathrm{O}$ slurry

As a result of sintering process, different structural shrinkage occurred with different ceramic formulations. In general the most complete replication copies were obtained with $\mathrm{Al}_{2} \mathrm{O}_{3}$ PVB-EtOH slurry. For this formulation the shrinking during sintering was lowest and the critical dimension and shape definition of micro-features changed the least. After sintering, the smallest transferred features from UV delivered molds were approximately $1.7 \mu \mathrm{m}$ diameter pillars (master dimension was $1.9 \mu \mathrm{m}$ ), and $3.2 \mu \mathrm{m}$-diameter wells (master dimension was $4.8 \mu \mathrm{m}$ ). These features were obtained from all three tape-casting slurries. For the LIL delivered master with $500 \mathrm{~nm}$ wide ridges only the PES-NMP based slurry containing zirconia ceramics resulted in a structured surface, however, the replication quality was very low (Fig. 4).

For both $\mathrm{Al}_{2} \mathrm{O}_{3}$ and $\mathrm{ZrO}_{2}$ based ceramics fabricated with PVB-EtOH and PES-NMP slurries, the grain structure on the surface of sintered specimens is clearly visible (Fig. 3a, b). In case of $\mathrm{Al}_{2} \mathrm{O}_{3}$ specimens delivered with $\mathrm{PVP}-\mathrm{H}_{2} \mathrm{O}$ slurry, this structure can only be observed in bulk material (Fig. 3c) and cannot clearly be observed on the surface of sintered material which appears to have a non-porous structure. The density of sintered bodies was measured with the Archimedes' method and ranged from the lowest for the NMP-PES-derived system $(88 \%)$ via PVB-EtOH-
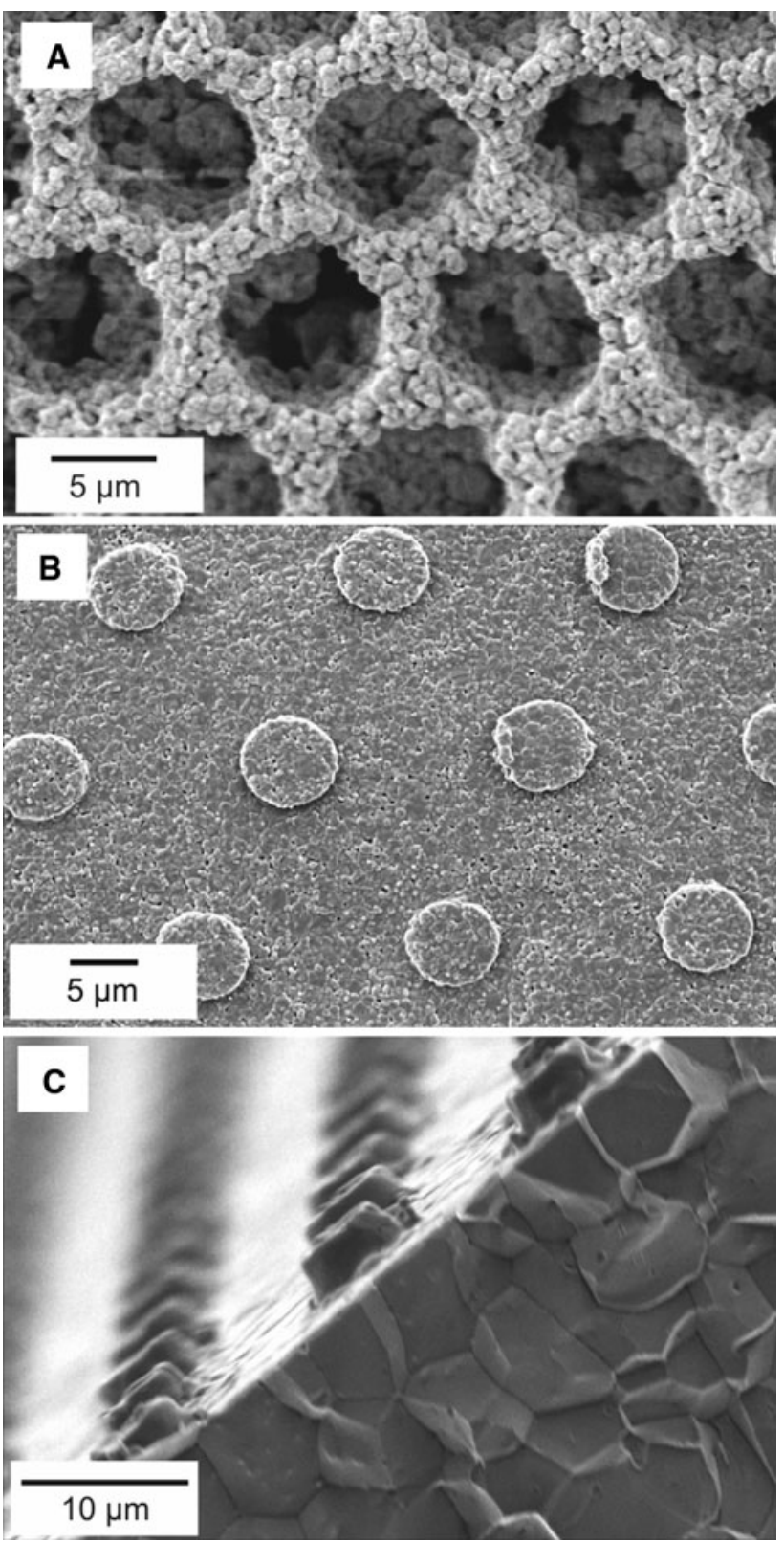

Fig. 3 Sintered in $1,500{ }^{\circ} \mathrm{C}$ ceramic bodies. a $6 \mu \mathrm{m}$ well structure created in $\mathrm{ZrO}_{2}$ with PES-NMP slurry. b $8 \mu \mathrm{m}$ well structure created in $\mathrm{Al}_{2} \mathrm{O}_{3}$ with PVB-EtOH slurry. c $\mathrm{Al}_{2} \mathrm{O}_{3}-\mathrm{PVP}-\mathrm{H}_{2} \mathrm{O}$ slurry delivered structures

derived $(96 \%)$ to the high-density $\mathrm{PVP}-\mathrm{H}_{2} \mathrm{O}$-derived system ( $99 \%$; relative values to theoretical density values of alumina and zirconia of $3.97 \mathrm{~g} \mathrm{~cm}^{-3}$ and $5.68 \mathrm{~g} \mathrm{~cm}^{-3}$, respectively). For the PVB-EtOH and $\mathrm{PVP}-\mathrm{H}_{2} \mathrm{O}$ derived alumina ceramics significant grain growth can be observed, where the largest grains were obtained for the PVP- $\mathrm{H}_{2} \mathrm{O}$ based slurry. The initial $\mathrm{Al}_{2} \mathrm{O}_{3}$ powder had a grain size of $0.3-0.5 \mu \mathrm{m}$. In the sintered body grains have grown to approximately $2.4 \mu \mathrm{m}$ in diameter for the $\mathrm{PVP}-\mathrm{H}_{2} \mathrm{O}$ slurry and $1.3 \mu \mathrm{m}$ in the green tapes obtained with the PVB- 

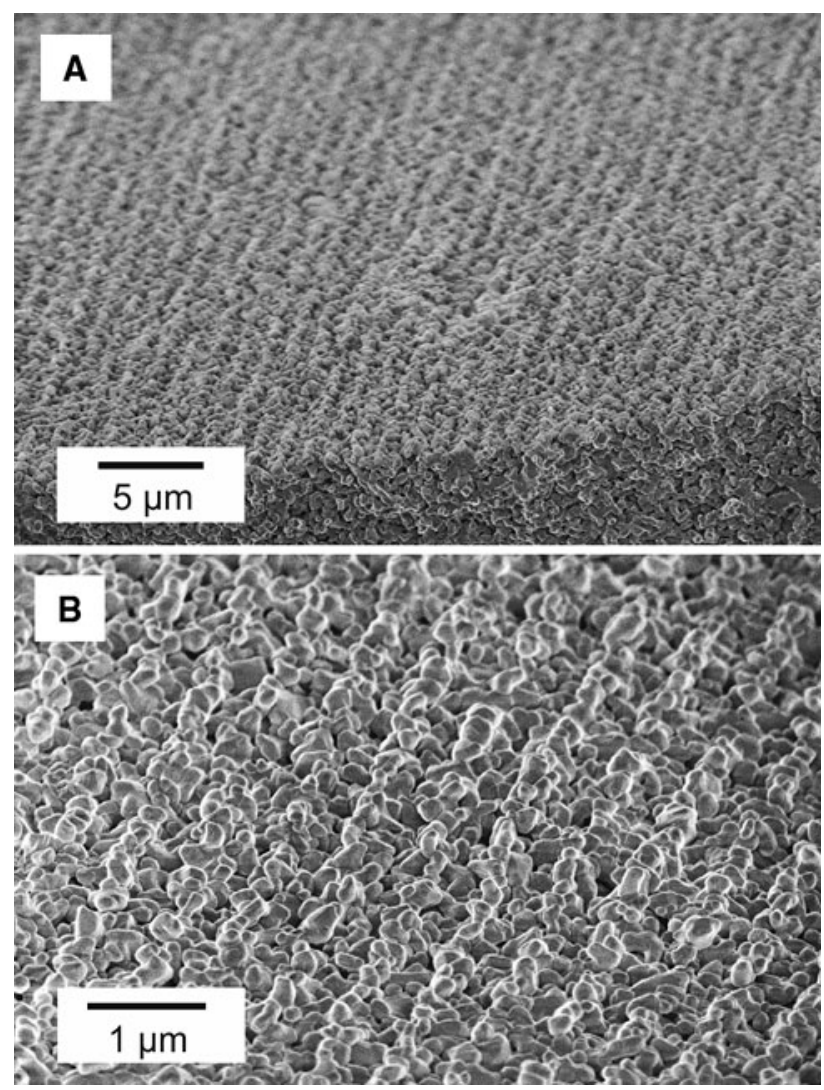

Fig. 4 Surface of nanopatterned sintered zirconia (PES-NMP slurry) shaped with $0.5 \mu \mathrm{m}$ silicon mold master delivered by LIL and RIE, barely visible ridges diminish due to the grain size

EtOH slurry. In case of zirconia powder the growth was also significant, the measured grain size in the sintered body was $0.48 \mu \mathrm{m}(0.05-0.08 \mu \mathrm{m}$ initially). Grain growth during sintering occurred to be the main limiting factor for copying structures with critical dimensions smaller than $6 \times D_{\text {grain }}$ (Fig. 4). Morphology measurements are summarized in Table 2.

\subsection{Cell culturing tests and results}

Rat dermal fibroblasts were cultured on alumina samples delivered from $\mathrm{Al}_{2} \mathrm{O}_{3}$ PVB-EtOH slurry. On flat alumina controls, fibroblasts were well-spread and formed normal spindle and multipolar cell morphologies with short filopodia. However, in contrast to cells cultured on standard cell culture polystyrene substrates (reference material, not shown), many focal contacts were visible at the cell edges (Fig. 6a) specifically adhering to the nanorough grain boundaries and small pores on the ceramic substrate surface. Fibroblast cells that had been cultured on the micropillar substrates were changing their morphology by stretching on the pillars. These cells also exhibited large filopodial extensions. Cell bodies covered the pillars and
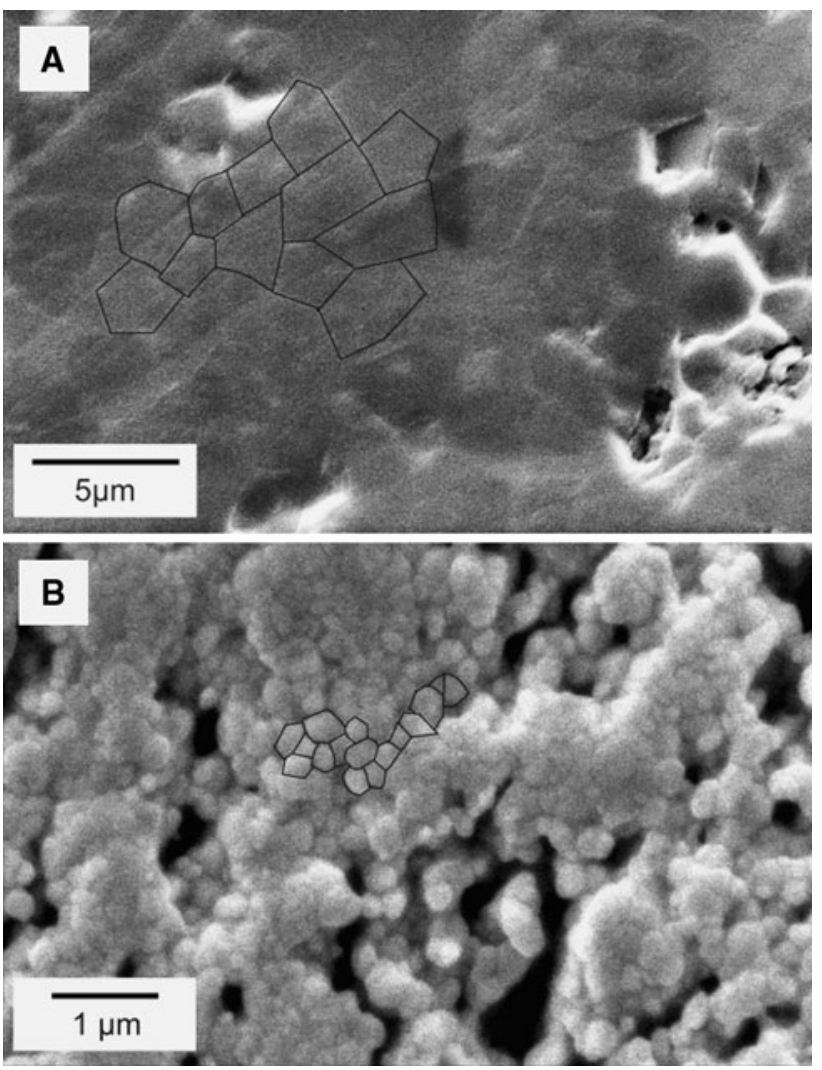

Fig. 5 The ceramic samples after sintering. Polishing and temperature etching were used to unveil grain boundaries. a Surface with outlined grain of alumina. b Surface with outlined grain of zirconia

descended down to the substrate surface around the pillars. The larger cell extensions clearly appeared to be guided by the pillars (Fig. 6b, c). No apparent differences in cell morphology were observed between all structural dimensions $(1.7,4.6$, and $8.6 \mu \mathrm{m})$ on which the cells were cultured on. Osteoblasts and fibroblasts have already been shown to respond to nanoroughness by increased filopodia formation and increased adhesive strength [22-24]. In accordance with these studies, the number of filopodia also appeared to increase on the currently tested micro-features structured alumina substrates. The observed phenomenon associated with such an event is a localization of $F$-actin, stress fibers and focal adhesions, marking the site of the discontinuities, edges, underlying the cell. The full effect of this phenomenon on an individual cell phenotype and differentiation pathway has yet to be deciphered [22-24].

\section{Conclusions}

In this work pattern transfer into ceramics was evaluated by tape casting from microfabricated silicon molds. These microfabricated ceramic surface structures could have application as a bio-active material. The influence of 
Table 2 Parameters of green tape and sintered ceramics

\begin{tabular}{|c|c|c|c|c|c|}
\hline \multirow[t]{2}{*}{ Composition } & \multicolumn{2}{|c|}{ Volume ratios in green state } & \multirow{2}{*}{$\begin{array}{l}\text { Density of } \\
\text { sintered body }\end{array}$} & \multirow{2}{*}{$\begin{array}{l}\text { Grain size in } \\
\text { sintered body }\end{array}$} & \multirow{2}{*}{$\begin{array}{l}\text { Shrinkage of sintered ceramic } \\
\left(D_{\text {mold }} / D_{\text {ceramics }}\right)\end{array}$} \\
\hline & Ceramics & Binder & & & \\
\hline $\mathrm{Al}_{2} \mathrm{O}_{3} \mathrm{PVB}-\mathrm{EtOH}$ & $70.4 \%$ & $29.6 \%$ & $96 \%$ & $1.3 \mu \mathrm{m}$ & 0.92 \\
\hline $\mathrm{Al}_{2} \mathrm{O}_{3} \mathrm{PVP}-\mathrm{H}_{2} \mathrm{O}$ & $76.9 \%$ & $23.0 \%$ & $99 \%$ & $2.4 \mu \mathrm{m}$ & 0.77 \\
\hline $\mathrm{ZrO}_{2}$ PES-NMP & $69.4 \%$ & $30.6 \%$ & $88 \%$ & $0.48 \mu \mathrm{m}$ & 0.66 \\
\hline
\end{tabular}
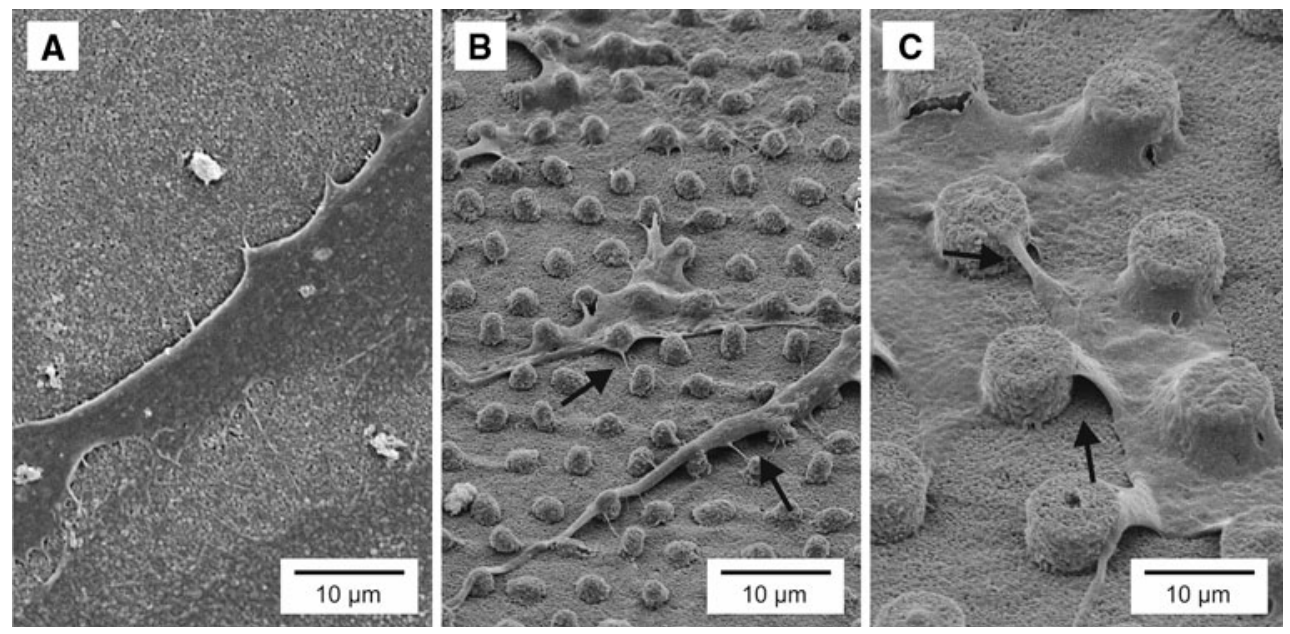

Fig. 6 SEM micrographs of fibroblasts (RDF) cultured on micropatterned substrates: a Flat alumina, b $1.7 \mu \mathrm{m}$ pillars, $\mathbf{c} 8.6 \mu \mathrm{m}$ pillars. The arrows indicate alternations in morphology of fibroblast caused by microstructure

surface features on cells was evaluated in fibroblast culture and morphology study. Here, we have used silicon molds with pillar- and well-like microstructures in a trigonal lattice arrangement as well as submicron sized ridge and grooves. Silicon mold microfabrication was based on photolithography (UV and LIL) and silicon dry reactive ion etching. This process provides a large flexibility in the design of microstructural layouts of surface features. Tape casting of the ceramic slurry on the surface of the silicon mold was used to replicate the silicon patterns in ceramics. It was found that all three investigated slurry systems $\left(\mathrm{Al}_{2} \mathrm{O}_{3}\right.$ PVB-EtOH, $\mathrm{Al}_{2} \mathrm{O}_{3}$ PVP- $\mathrm{H}_{2} \mathrm{O}, \mathrm{ZrO}_{2}$ NMP-PES $)$ were able to replicate well and pillar structures from the mold master down to $1.7 \mu \mathrm{m}$ and zirconia based slurry also ridge and groove structures in submicron size range. The sintered ceramics from different casting systems resulted in different densities and bulk microstructure. Initial grain size and grain growth during sintering were the main factors limiting small feature transfer from mold to final product. Using fine ceramic powders and preventing grain growth during sintering could lead to more uniform and well defined microstructures. The $\mathrm{Al}_{2} \mathrm{O}_{3} \mathrm{PVP}-\mathrm{H}_{2} \mathrm{O}$ slurry gave the ceramic bodies with the highest density and the $\mathrm{ZrO}_{2}$ NMP-PES gave the structures with the smallest grain size (note that for zirconia the initial grain size was also smaller). Finally to evaluate potential biomaterial-cell interactions, $\mathrm{RDF}$ were cultured on the microstructures delivered using $\mathrm{Al}_{2} \mathrm{O}_{3}$ PVP- $\mathrm{H}_{2} \mathrm{O}$ slurry which showed best structure replication performance. The findings from these cell cultures suggest that cells mainly react to micro pillars and wells by alterations in cell morphology and filopodia sensing. The cells recognize the patterns and respond by adapting a more stretched morphology including the formation of filopodia showing intimate contact with the surface features. The fact that alumina substrates possess an inherent nanoroughness can also influence cell behavior, as it was observed for combinations of other non-ceramic nano and microstructures [21]. It is recognized in literature as a "feature edge effect" and is also responsible for mechanisms like topographically induced cell guidance [4, 5],. Finally we conclude that tape on microfabricated silicon molds can be used to deliver microtopographies on ceramic surfaces with high reproducibility and good critical dimension control for biomaterial applications. 
Acknowledgments This project was sponsored by the Dutch Technology Foundation (STW NTH.7621).

Open Access This article is distributed under the terms of the Creative Commons Attribution License which permits any use, distribution, and reproduction in any medium, provided the original author(s) and the source are credited.

\section{References}

1. Best SM, Porter AE, Thian ES, Huang J. Bioceramics: past, present and for the future. J Eur Ceram Soc. 2008;28:1319-27.

2. Larry LH. Bioceramics: from concept to clinic. J Am Ceram Soc. 1991;74:1487-510.

3. Eisenbarth E, Meyle J, Nachtigall W, Breme J. Influence of the surface structure of titanium materials on the adhesion of fibroblasts. Biomaterials. 1996;17:1399-403.

4. Heydarkhan-Hagvall S, Choi C-H, Dunn J, Heydarkhan S, Schenke-Layland K, MacLellan WR, Beygui RE. Influence of systematically varied nano-scale topography on cell morphology and adhesion. Cell Commun Adhes. 2007;14:181-94.

5. Parker JA, Walboomers XF, Von den Hoff JW, Maltha JC, Jansen JA. The effect of bone anchoring and micro-grooves on the soft tissue reaction to implants. Biomaterials. 2002;23: 3887-96.

6. Pfeiffer F, Herzog B, Kern D, Scheideler L, Geis-Gerstorfer J, Wolburg H. Cell reactions to microstructured implant surfaces. Microelectron Eng. 2003;67-68:913-22.

7. Balasundaram G, Sato M, Webster TJ. Using hydroxyapatite nanoparticles and decreased crystallinity to promote osteoblast adhesion similar to functionalizing with RGD. Biomaterials. 2006;27:2798-805.

8. Treccani L, Maiwald M, Zöllmer V, Busse M, Grathwohl G, Rezwan K. Antibacterial and abrasion-resistant alumina micropatterns. Adv Eng Mater. 2009;11:B61-6.

9. Zhou YS, Ikeuchi K, Ohashi M. Comparison of the friction properties of four ceramic materials for joint replacements. Wear. 1997;210:171-7.

10. Rieu J. Ceramic formation on metallic surfaces (ceramization) for medical applications. Clin Mater. 1993;12:227-35.

11. Kusaka J, Takashima K, Yamane D, Ikeuchi K. Fundamental study for all-ceramic artificial hip joint. Wear. 1999;225-229: $734-42$.
12. Young AC, Jane-Chyi L, Tsung-Shou Y, Chian-Lii C. Characteristics of tape casting slurries containing forsterite, PVB and organic solvent. Mater Chem Phys. 1993;34:147-53.

13. Liu Y, Chen OY, Wei CC, Li K. Preparation of yttria-stabilised zirconia (YSZ) hollow fibre membranes. Desalination. 2006; 199:360-2.

14. Lin Y-S, Burggraaf AJ. Preparation and characterization of hightemperature thermally stable alumina composite membrane. J Am Ceram Soc. 1991;74:219-24.

15. Hu JM, Beck RG, Deng T, Westervelt RM, Maranowski KD, Gossard AC, Whitesides GM. Using soft lithography to fabricate GaAs/AlGaAs heterostructure field effect transistors. Appl Phys Lett. 1997;71:2020-2.

16. Schonholzer UP, Stutzmann N, Tervoort TA, Smith P, Gauckler LJ. Micropatterned ceramics by casting into polymer molds. J Am Ceram Soc. 2002;85:1885-7.

17. Xu ZL, Qusay FA. Polyethersulfone (PES) hollow fiber ultrafiltration membranes prepared by PES/non-solvent/NMP solution. J Membr Sci. 2004;233:101-11.

18. Mendelson MI. Average grain size in polycrystalline ceramics. J Am Ceram Soc. 1969;52:443-6.

19. Kwan Y-BP, Alcock JR. The impact of water impregnation method on the accuracy of open porosity measurements. J Mater Sci. 2002;37:2557-61.

20. Freshney RI. Freshney's culture of animal cells, a multimedia guide. New York: Wiley-Liss; 1999.

21. Puckett S, Pareta R, Webster TJ. Nano rough micron patterned titanium for directing osteoblast morphology and adhesion. Int $\mathrm{J}$ Nanomedicine. 2008;3:229-41.

22. Dalby MJ, Berry CC, Riehle MO, Sutherland DS, Agheli H, Curtis ASG. Attempted endocytosis of nano-environment produced by colloidal lithography by human fibroblasts. Exp Cell Res. 2004;295:387-94.

23. Mustafa K, Oden A, Wennerberg A, Hultenby K, Arvidson K. The influence of surface topography of ceramic abutments on the attachment and proliferation of human oral fibroblasts. Biomaterials. 2005;26:373-81.

24. Loesberg WA, te Riet J, van Delft FC, Schön P, Figdor CG, Speller S, van Loon JJ, Walboomers XF, Jansen JA. The threshold at which substrate nanogroove dimensions may influence fibroblast alignment and adhesion. Biomaterials. 2007;28: 3944-51. 